\title{
Comparative Vulnerability Assessment of Urban Heat Islands in Two Tropical Cities in Indonesia
}

\author{
Tumiar K. Manik $^{1^{*}}$ and Syarifah Syaukat ${ }^{2}$ \\ ${ }^{1}$ University of Lampung, Sumantri Brojonegoro 1, Bandar Lampung 35136, Indonesia. \\ ${ }^{2}$ Center for Applied Geography Research, Universitas Indonesia, Jakarta, Indonesia.
}

\begin{abstract}
Authors' contributions
This work was carried out in collaboration between both authors. Author TKM designed the study, coordinated data collection for Bandar Lampung area, performed the statistical analysis and wrote the first draft of the manuscript. Author SS coordinated data and map collection for Jakarta area and managed the literature searches. Both authors read and approved the final manuscript.
\end{abstract}

Article Information

DOI: 10.9734/BJECC/2017/33529

Original Research Article

Received $19^{\text {th }}$ April 2017

Accepted $24^{\text {th }}$ May 2017

Published $3^{\text {rd }}$ July 2017

ABSTRACT

Aims: To identify whether the urban heat island (UHI) phenomena occurs in Jakarta, a metropolitan city with business and industrial background, and Bandar Lampung, a growing city with agricultural background; to identify community vulnerability and adaptation to UHI impacts.

Place and Duration of Study: This research was conducted in selected area in Jakarta and Bandar Lampung, between September to November 2013.

Methodology: This study used direct air temperature measurements and satellite observation to identify UHI phenomena. The communities vulnerability was assesed with distributing questionnaires and interviewing households, the questions were tailored to fit the components of vulnerability: exposure, sensitivity and adaptive capacity. Vulnerability index is composed of exsposure and sensitivity. The exposure was compiled from community knowledge about climate change and temperature rising and the observed air temperature. The sensitivity was composed of water availability, health related to temperature rising, electricity need; and the adaptive capacity was composed of social relationship, education, income and house environment.

Results: UHI profile was identified in the morning in Bandar Lampung but not in Jakarta. In the afternoon, the UHI still existed in Bandar Lampung but weaker than in the morning, in Jakarta the $\mathrm{UHI}$ existed stronger; in the evening UHI was not identified in both cities. The temperature difference could be $4^{\circ} \mathrm{C}$ in Bandar Lampung and $5^{\circ} \mathrm{C}$ in Jakarta. Both the LVI and the LVI-IPCC index indicated that Bandar Lampung was less vulnerable to UHI impacts compared to Jakarta (0.303 compared to 0.311 and -0.011 compared to -0.017 ) both were categorized as moderate. 
Conclusion: UHI is present both in Jakarta and Bandar Lampung, and this effect might related to the patterns of land cover in general. The residents both Bandar Lampung and Jakarta have average levels of vulnerability to temperature rises, with Bandar Lampung slightly less vulnerable compared to Jakarta.

Keywords: Urban heat island; vulnerability; adaptation; Indonesia.

\section{INTRODUCTION}

Urbanisation is occurring across Indonesia. The World Bank projects that between 2010 and 2025 the population of 11 big cities in Indonesia (including Jakarta and Bandar Lampung) will increase by an average of 309,000 people per year [1]. By 2025, approximately 67.5 per cent of Indonesia's population will live in urban areas (ibid). In terms of urban growth rates, Indonesia and China have urbanised most rapidly in percentage terms in the period from 1970 to 2010. The trends indicate that Indonesia is likely to continue to urbanise at relatively high rates for the next decade. Java is the most urbanised region, with almost 50 per cent of its population living in urban areas, followed by Kalimantan and Sumatra with 36.3 and 34.0 per cent respectively [1].

Alongside this urbanisation, the impacts of climate change are being felt increasingly. Air temperatures are slowly rising as one consequence of global climate change, with adverse effects including melting Arctic sea ice, rising sea levels, increased frequency and intensity of tropical storms, changes in the air circulation pattern and alterations in seasonal patterns [2]. At the local scale, especially in urban areas, waste heat produced by human activities, including heat generated by vehicle combustion and industrial processes, the conduction of heat through building walls or emitted directly into the atmosphere by airconditioning systems, and the metabolic heat produced by humans all combine to cause local air temperatures to rise, especially in urban areas. This phenomenon is known as 'urban heat islands' (UHI) [3]. Elevated global temperatures may thus be compounded by the additional stress resulting from the urban heat island phenomenon. As a result, it is expected that the effects of climate change on rising temperatures will be felt most severely in the world's cities or urban areas [4].

\subsection{What are Urban Heat Islands?}

The urban heat island (UHI) effect is the magnitude of the difference in observed ambient air temperature between cities and their surrounding rural regions [5]. The magnitudes of the differences can be quite large at times depending on weather conditions, urban thermophysical and geometrical characteristics, and anthropogenic moisture and heat sources present in the area.The UHI is created primarily by dense concentrations of heat-absorbing, impervious building materials that trap more heat during the day and release it more slowly at night than natural ground cover, such as soil and vegetation [6].

At the regional scale, land-use patterns and land cover are the strongest drivers of urban temperatures. Urbanisation replaces vegetated surfaces - which provide shading, evaporative cooling and rainwater interception, storage and infiltration functions - with impervious built surfaces [7]. Currently, 54 per cent of the world's population lives in urban areas, of which nearly half live in smaller settlements of fewer than 500,000 inhabitants [8]. Population growth and continued urbanisation are expected to add another 2.5 billion urban dwellers by 2050 , and 90 per cent of this increase is expected to be in Africa and Asia [1]. In this context, it is important to understand the potential for UHI effects to manifest themselves, and how urban populations can adapt to these effects to minimise the risks to their lives.

Some researchs showed the UHI existed in Asia countries. [9] examined land surface temperature patterns and their relationship with land cover in Guangzhou and in urban clusters in the Zhujiang Delta, China and concluded from a remote sensing investigation that vegetation abundance is one of the most influential factors in controlling land surface temperatures. The temperature difference recorded in Chennai metro area was $3.6^{\circ} \mathrm{C}$ in summer and $4.1^{\circ} \mathrm{C}$ in winter [10]; Malaysia $3.9^{\circ} \mathrm{C}$ to $5.5^{\circ} \mathrm{C}$ [11]; Many previous studies have indicated that the UHI intensity was related to local meteorological conditions [2]. In Seoul, Korea, the most prominent occurrence of the maximum $\mathrm{UHI}$ intensity has a peak at $4.5^{\circ} \mathrm{C}$ when there is zero cloud cover [12]. In Metro Manila, The Philipines the temperature difference was $2.96^{\circ} \mathrm{C}$ [13], In the UK the largest heat 
island is found in London with night-time temperatures up to $7^{\circ} \mathrm{C}$ warmer than rural temperatures $20 \mathrm{~km}$ away. Notably the greatest urban heat island intensity in London is experienced overnight with the lowest increased urban temperature being in the early afternoon [4]. The spatial variability in temperatures measured traversed across the urban area of Portland on hot days showed that temperatures varied by $5.5^{\circ} \mathrm{C}$ across the area measured, while in New York 40C in summer and fall and 30C in winter and spring [14].

These observations show that temperature rises and the UHI effect is evident in urban areas, though there is scope for further research in understanding the vulnerability of local populations to UHIs. As this could affect the quality of life for urban residents, this study seeks to fill this research gap for Jakarta, the capital city of Indonesia, and Bandar Lampung, a medium-sized city.

\subsection{What are the Impacts of Urban Heat Islands?}

Urban heat islands (UHIs) have the potential to become one of the largest problems associated with the urbanisation and industrialisation of human civilisation, as the increased temperatures associated with UHls tend to exacerbate the threats to human health posed by thermal stress. As a result, the UHI has been a central theme among climatologists, and is well documented in many metropolitan areas around the world [15].

The IPCC reports that incidences of heatwaves increased towards the end of the 20th century and are projected to continue to increase in frequency, intensity and duration worldwide (IPCC, 2007). The actual impacts of urban climate change and heat islands depend on the characteristics of local climates. Exposure to excessively warm weather is a global threat to human health and well-being. Most UHI impact studies related UHI impacts on human health on hot days. Heat related illness includes: heat stress, heat cramps, heat syncope, heat edema, heat exhaustion and heat stroke [16]. Studies of heatwaves and mortality in Shanghai, China [15] and in the USA $[17,18,19]$ demonstrated that days with increased temperatures or periods of extended high temperatures have increased heat-related mortality. More deaths are attributed to heat in temperate climates than in warm climates because people in temperate zones are less acclimatised to high temperatures $[20,21]$.

\subsection{Vulnerability Assessments of Urban Heat Island Impacts}

Vulnerability assessments are needed to assess the extent to which communities are vulnerable to changing environmental conditions, and thus identify what steps they should take to adapt to these changes. In this study, the vulnerability assessment tried to bridge the gap between the social, natural and physical sciences, and by doing so aims to contribute new methodologies which could be applied in other urban areas. Whilst there are a variety of approaches to carrying out vulnerability assessments, many of the methods rely heavily on the IPCC working definition of vulnerability as a function of exposure, sensitivity and adaptive capacity [22]. Vulnerability hence assesses the degree to which a system is susceptible to, and unable to cope with, adverse effects of climate change, including climate variability and extremes and in the context of this study, the vulnerability of urban residents is the focus. Within the hazards literature, vulnerability has many different connotations, depending on the research orientation and perspective. Physical vulnerabilities are the amount of potential damage that can be caused to a system by a particular hazard [23].

Social vulnerability on the other hand is determined by factors such as poverty, inequality, marginalisation, access to health and housing quality [24]. Vulnerability defines the extent to which people are susceptible to harm from or unable to cope with a particular hazard $[25,26]$.

\subsection{Approaches to Assessing Vulnerabi- lity}

The vulnerability assessment process can include a diverse set of methods used to systematically integrate and examine interactions between humans and their physical and social surroundings.The IPCC definition can be expressed as: vulnerability = function [exposure $(+)$; sensitivity (+); adaptive capacity (-)] [27]. Exposure refers to the degree to which a system is exposed to significant climatic variations. Sensitivity refers to the degree to which a system 
is affected, either adversely or beneficially, by climate-related stimuli, whilst adaptive capacity is the ability of a system to adjust to climate change (including climate variability and extremes) to moderate potential damage, to take advantage of opportunities, or to cope with the consequences [27].

A common approach to assessing vulnerability goes through the following steps: selection of adequate indicators (e.g. statistical data about the population being studied) and geographic information system (GIS) and remote sensing (RS) (geodata, administrative units, and thermal data) for calculating the exposed area. Sensitivity is calculated using indicators such as age and unemployment. The data is then normalised, weighted and aggregated in a composite indicator [9]. [28] concluded that while several vulnerability indices have been developed, all have been criticised, and none have been widely used. An index that focuses on one type of impact in one region is likely to be more informative and useful, whilst retaining the multiple dimensions of vulnerability. In short, the development of vulnerability indices continues to present an academic challenge. Vulnerability assessments require different information, methodologies and spatial and temporal scale depending their objectives, and the appropriate indicators can be elicited by feedback from expert meetings and interviews with public officials [18].
In this study, the vulnerability index approach based on the IPCC definition was chosen as the most widely used index. However, as a vulnerability study specific to UHI is new both in Bandar Lampung and Jakarta, there is no existing UHI vulnerability index in these areas. Therefore, two approaches are used in this index. The first is comprised of the livelihood vulnerability index (LVI) as a composite index comprised of major components, while the second aggregates the major components into the three contributing factors to vulnerability: exposure, sensitivity and adaptive capacity [22]. The LVI uses a balanced weighted average method where each sub-component contributes equally to the overall index even though each major component is comprised of a different number of subcomponents. LVI is intended as an assessment tool accessible to diverse users in resource-poor settings.

\section{METHODOLOGY}

\subsection{Investigating Urban Heat Islands in Bandar Lampung and Jakarta}

\subsubsection{Field air temperature observations}

In each city, certain locations was chosen following UHI model (Fig. 1); locations which represent rural/green area, residential area, bussiness area and central city.

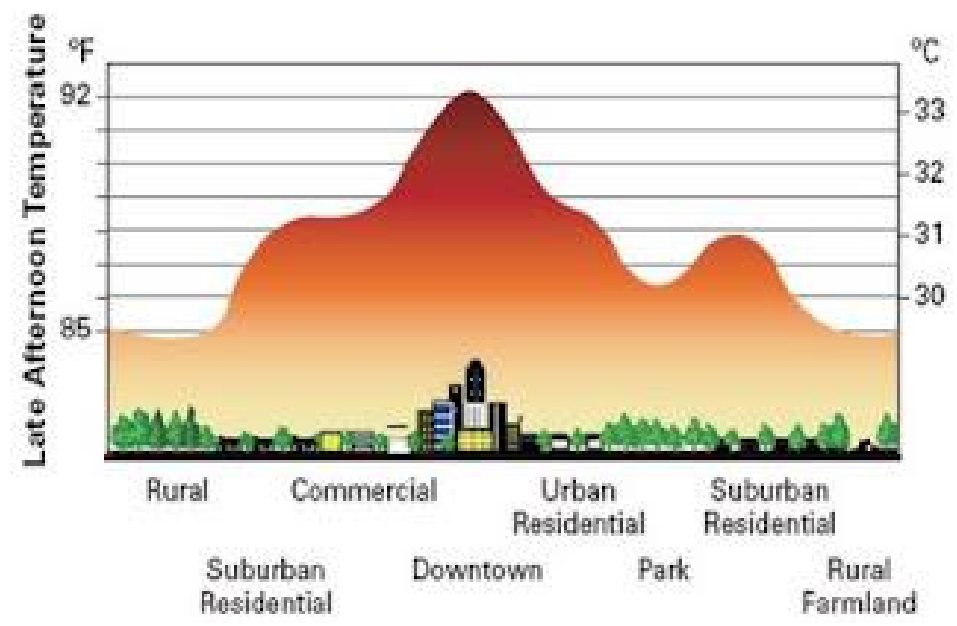

Fig. 1. Urban heat unit profile

Source: From: Heat Island Group. Lawrence Berkeley National Laboratory in Sailor [29] 
Table 1. List of study areas in Jakarta and Bandar Lampung

\begin{tabular}{llll}
\hline & & City: Jakarta & \\
\hline No & Location & Geography position (E; S) & Land cover type \\
\hline 1 & Semanan, Kalideres & $106.705 ;-6.160$ & Agriculture \\
2 & D Kosambi,Cengkareng & $106.723 ;-6.171$ & Commercial \\
3 & D Kosambi,Cengkareng & $106.741 ;-6.158$ & Industry/warehousinggg \\
4 & Kembangan Selatan & $106.750 ;-6.182$ & Low density urban \\
5 & Kedoya Utara, K Jeruk & $106.762 ;-6.160$ & High density urban \\
6 & Gambir & $106.820 ;-6.180$ & Government Facility \\
7 & Gambir & $106.820 ;-6.180$ & Open Space \\
8 & Johar Baru & $106.870 ;-6.174$ & High Density Urban \\
9 & Cempaka Putih Timur & $106.870 ;-6.174$ & Commercial/Industry \\
10 & Kayu Putih, P Gadung & $106.888 ;-6.186$ & Low density urban \\
\hline & & City: Bandar Lampung & \\
\hline No & Location & Geography position & Land cover type \\
\hline 1 & Lematang, Tj Bintang & $105.34843 ; 5.401050$ & Industries \\
2 & Sukabumi Indah & $105.29460 ;-5.400000$ & Residentials \\
3 & Kutoarjo, Gd Tataan & $105.08635 ;-5.374183$ & Paddy, agriculture \\
4 & Beringin raya Kemiling & $105.20557 ;-5.402550$ & Residentials \\
5 & Palapa, Tj Karang & $105.25153 ;-5.417833$ & Bussiness \\
6 & Teluk Betung & $105.26753 ;-5.446350$ & Bussiness \\
7 & Panjang Selatan & $105.32541 ;-5.477983$ & Coastal \\
8 & Nunyai, Rajabasa & $105.23346 ;-5.373667$ & Residentials \\
9 & Sindangsari, Natar & $105.20460 ;-5.330550$ & Estate, agriculture \\
\hline
\end{tabular}

Spatial distribution for air temperature distribution particularly to investigate the existance of urban heat unit will be measured followings these steps:

1. Temperature data in the chosen study areas were collected by points air thermometer measurements. Temperature measurement was accomplished in 2 months (September- November 2013)

2. Thermometer was distributed to the communities and they measured the air temperature 3 times a day: $7 \mathrm{am}, 01 \mathrm{pm}$ and $05 \mathrm{pm}$

3. The temperature data should be reported daily to the researchers via cell phone

4. Using kriging spatial analysis, spatial temperature data distribution with its geographic position could be attained.

\subsection{Identifying Community Vulnerability to Urban Heat Islands}

Vulnerability assesment had been done with distributing questionaires and interviewing housholds in chosen community based on land use type. Forty residents in each area was chosen randomly with no spesific criteria. Items in questionaire were compiled based on some experience in former study and discussions among the team. The questions should be fit to the components and criterias in IPCC's index: exposure, sensitivity and adaptive capacity (Fig. 2).

\subsubsection{Main indicators and sub-indicators}

This study composed main indicators and sub indicators for calculating the vulnerability indices as presented in Table 2.

\subsubsection{Calculating LVI-IPCC index}

\subsubsection{Standardizing indices}

Since the unit of each sub-indicator will be different, it is necessary to standarize the unit with the formula

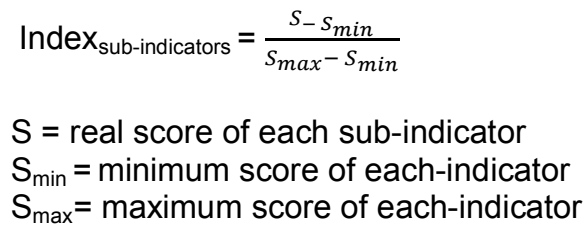

\subsubsection{Averaging sub-indicators indices}

$\mathrm{M}_{\text {sub-indicator }}=\frac{\sum_{i=1}^{n} \text { Index }_{\text {of sub-indicators }}}{n}$ 


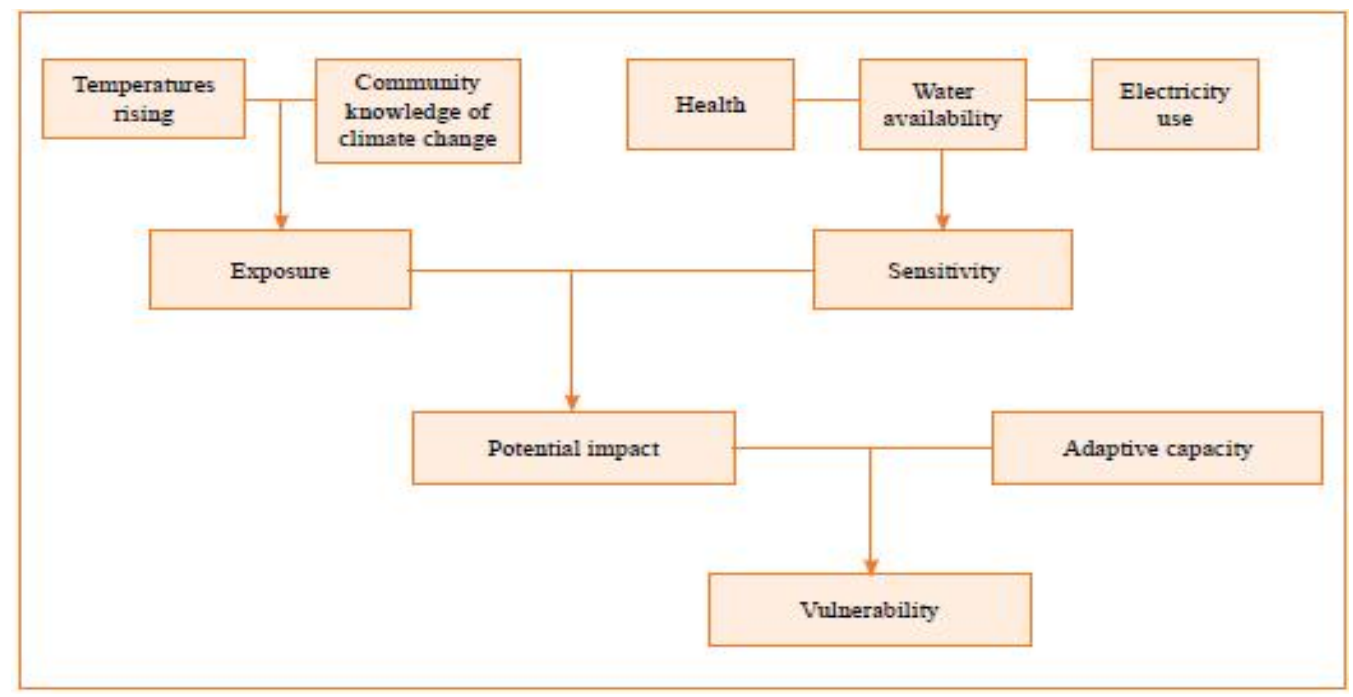

Fig. 2. Framework for index to assess communities' vulnerability

Table 2. Main indicators and sub-indicators using of the exposure, sensitivity and adaptive capacity for calculating the vulnerability index

\begin{tabular}{|c|c|c|c|}
\hline No & Subjects & Main indicators & Sub-indicators \\
\hline \multirow[t]{2}{*}{1} & \multirow[t]{2}{*}{ Exposure } & $\begin{array}{l}\text { Community } \\
\text { knowledge of climate } \\
\text { changing }\end{array}$ & $\begin{array}{l}\text { Percentage of households that aware of temperature } \\
\text { rising; percentage of households that feel of } \\
\text { temperature rising in the last } 3 \text { years; percentage of } \\
\text { households that understands the causes of } \\
\text { temperature rising; percentage of households that } \\
\text { realize the impacts of temperature rising. }\end{array}$ \\
\hline & & Climate variability & $\begin{array}{l}\text { Average monthly temperature deviation from long } \\
\text { term temperature }\end{array}$ \\
\hline \multirow[t]{3}{*}{2} & \multirow[t]{3}{*}{ Sensitivity } & Water availability & $\begin{array}{l}\text { Percentage of households having water problems; } \\
\text { percentage of households using water from natural } \\
\text { source for bussiness; percentage of households using } \\
\text { water from natural source for daily life; time } \\
\text { consuming to reach the natural water resource; water } \\
\text { needs for each household; monthly expenses for } \\
\text { water needs; distance from house to water source }\end{array}$ \\
\hline & & $\begin{array}{l}\text { Health related to air } \\
\text { temperature }\end{array}$ & $\begin{array}{l}\text { Percentage of households suffering from illness } \\
\text { related to temperature rising; percentage of diseases } \\
\text { preventation caused by temperature rising; } \\
\text { percentage of households that family numbers were } \\
\text { sick that are not able to do normal activities; average } \\
\text { distance from home to health facilities; average } \\
\text { households expenses for health; percentage of } \\
\text { households having health insurance; percentage of } \\
\text { households getting support for health expenses }\end{array}$ \\
\hline & & Energy consumption & $\begin{array}{l}\text { Percentage of households with no electricity; average } \\
\text { capacity of electricity usage; percentage of } \\
\text { households adding more capacity to cope with } \\
\text { temperature rising; average expenses for electricity }\end{array}$ \\
\hline 3 & $\begin{array}{l}\text { Adaptive } \\
\text { capacity } \\
\text { (Community) }\end{array}$ & Social relationship & $\begin{array}{l}\text { Percentage of households being active in social } \\
\text { organization; ratio of households receiving/giving } \\
\text { supports from/to others; percentage of households }\end{array}$ \\
\hline
\end{tabular}




\begin{tabular}{lll}
\hline No Subjects & Main indicators & Sub-indicators \\
\hline & $\begin{array}{l}\text { that give their supports to the neigborhood; average } \\
\text { number of community organization; average number } \\
\text { of organization related to environment; percentage of } \\
\text { households involving in any program related to } \\
\text { temperature rising }\end{array}$ \\
\cline { 2 - 3 } & $\begin{array}{l}\text { Percentage of households having education lower } \\
\text { than } 6 \text { years }\end{array}$ \\
\hline Income & $\begin{array}{l}\text { Percentage of households having only one source of } \\
\text { income; percentage of households having additional } \\
\text { income beside the main job }\end{array}$ \\
\hline House adaptation & $\begin{array}{l}\text { Percentage of households that modifying house type; } \\
\text { percentage of house having AC or fan; percentage of } \\
\text { households having non permanent house; average } \\
\text { house building size; distance of a house with right } \\
\text { left, back neighbours; percentage of house with } \\
\text { metal/asbes roof; percentage of households having } \\
\text { permanent house }\end{array}$ \\
\hline
\end{tabular}

\subsubsection{Calculating main indicator indices}

$$
\text { Index } x_{\text {main indicators }}=\frac{\sum_{i=1}^{n} W_{M i} M_{S u b-\text { indicator } i}}{\sum_{i=1}^{7} W_{M i}}
$$

$\mathrm{W}=$ weighing factor

\subsubsection{Calculating IPCC vulnerability index}

$$
\mathrm{CF}_{(\mathrm{e}, \mathrm{a}, \mathrm{s})}=\frac{\sum_{i=1}^{n} W_{M i} M_{\text {main indicator } i}}{\sum_{i=1}^{7} W_{M i}}
$$

CF = contribution factor of e (exposure), a (adaptive capacity) and s (sensitivity)

$$
\mathrm{VI}_{\text {IPCC }}=(e-a)^{*} S
$$

$\mathrm{VI}=$ Vulnerability index

LVI is ranged between 0 (low vulnerable) to 1 (highly vurnerable), while

LVI-IPCC is ranged between -1 (low vulnerable) to +1 (highly vulnerable).

\section{RESULTS AND DISCUSSION}

\subsection{Identification of UHI Based Observed Air Temperature}

\subsubsection{Bandar Lampung}

Air temperature profile in morning (Fig. 3a) showed that air temperature tended to rise toward the central city, at maximum the temperature difference could be $4^{\circ} \mathrm{C}$. Residential area has similar $\left(28^{\circ} \mathrm{C}\right)$ air temperature with central city since central city in Bandar Lampung was not occupied with tall buildings and still had enough open space. The agriculture area had the lowest temperature $\left(25^{\circ} \mathrm{C}\right)$ as expected; however in a palm oil plantation area had high temperature similar with the central city. Palm oil tended to use soil water made this area dry, also this area had wide bare land because of opening new area of palm plantation.

In the afternoon (Fig. 3b) agriculture area, residential area and the bussiness/government area in the central city shared the similar temperature $\left(30-31^{\circ} \mathrm{C}\right)$. High temperature (33$34^{\circ} \mathrm{C}$ ) happened toward commercial and industries area in coastal area. As in the morning, at maximum the temperature difference could reach $4^{\circ} \mathrm{C}$.

In the evening (Fig. 3c) air temperature did not show specific profile, it was almost flat $\left(29-30^{\circ} \mathrm{C}\right)$. Some high temperature spots $\left(>31^{\circ} \mathrm{C}\right)$ found in residential area probably caused by open land area that still emitted radiation to the atmosphere, and bussiness area toward coastal area. In average, air temperature in Bandar Lampung is $29^{\circ} \mathrm{C}$, the coolest area is on agricultural land cover and the hottest is the bussiness area near coast line.

\subsubsection{Jakarta}

Morning temperature profile of Jakarta was presented in Fig. 4. The figures showed that in the morning (Fig. 4a) most areas in Jakarta had similar temperature about $29^{\circ} \mathrm{C}$, some places had higher temperature $\left(29.6^{\circ} \mathrm{C}\right.$ and $\left.31.1^{\circ} \mathrm{C}\right)$. This happen in an area of high density settlement and in an area occupied with commercial/ bussiness buildings and high density settlement. Dense houses and buildings caused the air temperature higher compared to other areas. 

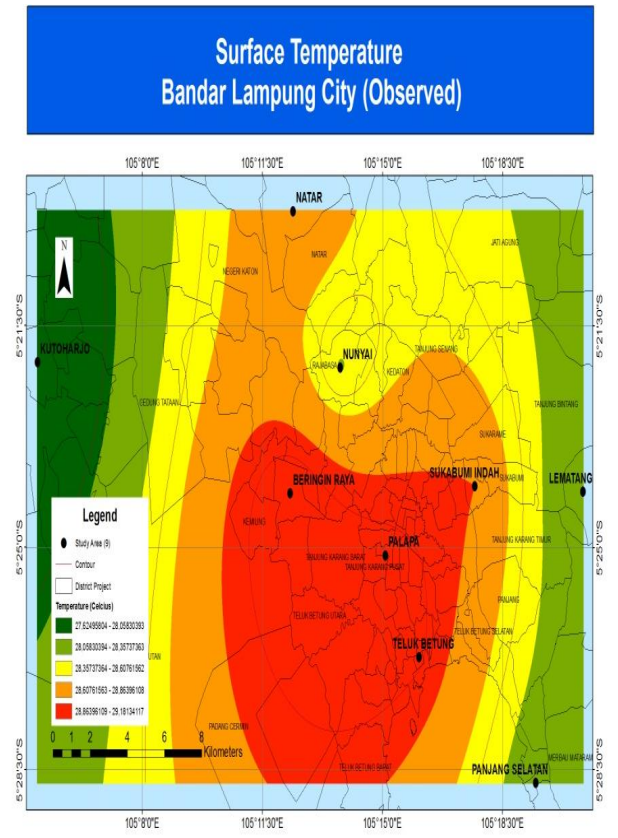

(a)
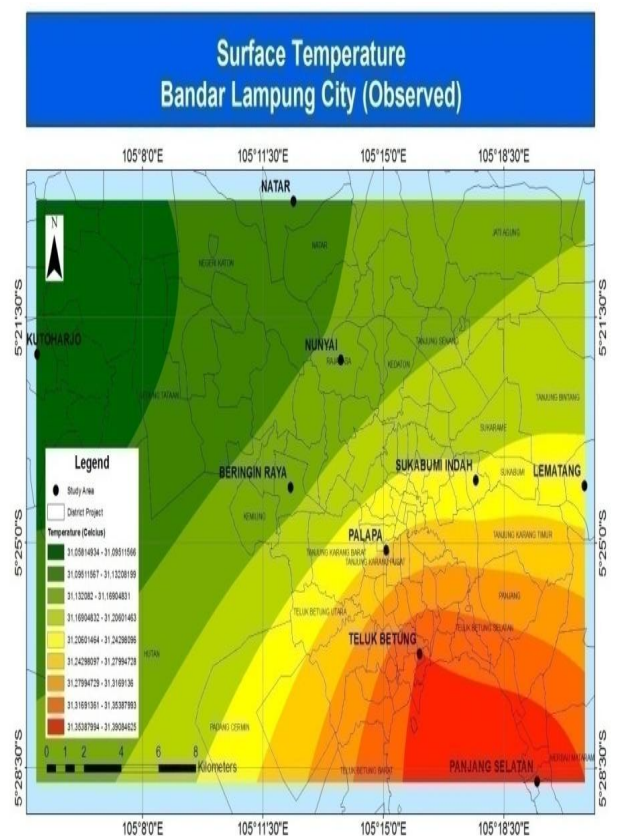

(b)

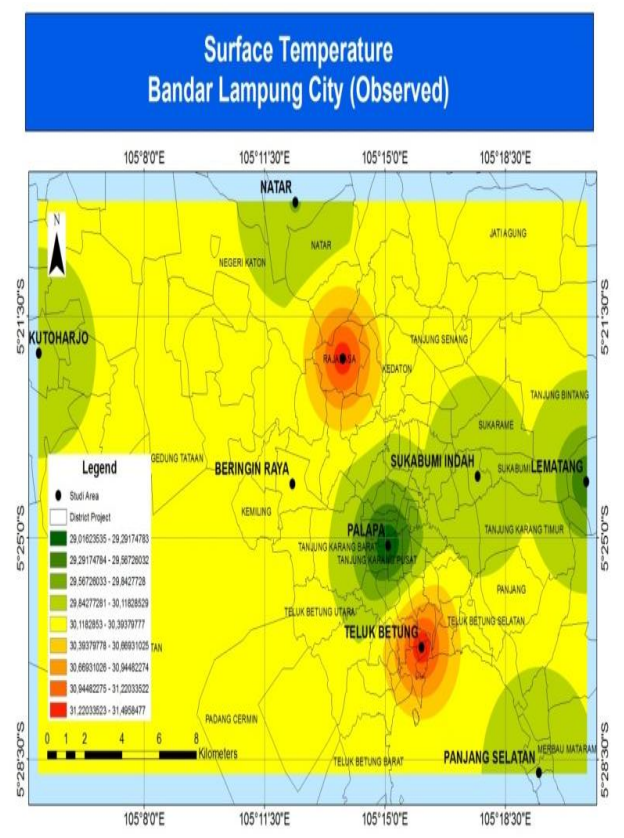

(c)

Fig. 3. Spatial distribution of observed morning (a), noon (b) and evening (c) air temperature in Bandar Lampung 
Afternoon temperature profile (Fig. 4b) showed that $\mathrm{UHI}$ is identified in Jakarta with temperature different was about $5^{\circ} \mathrm{C}$. The area that still dominated by agriculture coverage, settlement area), an in area with part is commercial area had similar temperature $\left(30-31^{\circ} \mathrm{C}\right)$, An industrial area had higher temperature $\left(31.73^{\circ} \mathrm{C}\right)$; in the government buildings area the temperature raised to $32^{\circ} \mathrm{C}$. The highest $\left(35.40^{\circ} \mathrm{C}\right.$ and $33.50^{\circ} \mathrm{C}$ ) reached both in high density residential area.

Evening temperature profile (Fig. 4c) did not show UHI pattern. The high temperature area was still Cempaka Putih $\left(33.17^{\circ} \mathrm{C}\right)$ and Duri Kosambi in industrial area $\left(32.82^{\circ} \mathrm{C}\right)$. In the average Jakarta temperature profile (Fig. 6) identified UHI pattern, the air temperature was rising toward the central industrial area.

\subsection{Identification of UHI Sattelite Observations}

\subsubsection{Bandar Lampung}

Sattelite observations (Fig. 5) on September 8, 2013 identified $\mathrm{UHI}$ in Bandar Lampung; the air temperature in agriculture area was $27-29^{\circ} \mathrm{C}$ ), the residential area and industrial area had a bit higher temperature $\left(29-32^{\circ} \mathrm{C}\right)$ and finally the central city, bussines area and coastal area had the highest temperature $\left(32-34^{\circ} \mathrm{C}\right)$. The sattelite observation on October 19, 2013 showed that the agriculture and residential area had similar temperature about $31^{\circ} \mathrm{C}$; while the central city, bussines area and coastal area had similar temperature about $34^{\circ} \mathrm{C}$. In hotter day October 28, 2013 all Bandar Lampung area had air temperature about $32-34^{\circ} \mathrm{C}$.

\section{$\underline{3.2 .2 ~ J a k a r t a}$}

From satellite observation Jakarta was looked like a big hot island both when the day was hot (July $8^{\text {th }}, 2013 ; 31-34^{\circ} \mathrm{C}$ ) and when it was cooler (July $15^{\text {th }}, 2013 ; 28^{\circ} \mathrm{C}$ ) (Fig. 6). Some areas that tend to have lower temperature were on North Jakarta.

\subsubsection{Comparing Bandar Lampung and Jakarta}

UHI profile was identified in the morning in Bandar Lampung but not in Jakarta. When solar radiation reaches the earth surface it is divided into latent heat for evaporating the moisture of land surface and sensible heat for rising the air temperature. Lower temperature in suburban area in Bandar Lampung proved that the area was more humid in the morning than in central city; this could imply that land cover of the area surrounding Bandar Lampung still dominated by vegetation. Compared to Bandar Lampung, in Jakarta all area was dry even in the morning that the solar radiation directly rise the air temperature and did not create temperature difference with central city area.

In the afternoon, the UHI still existed in Bandar Lampung but weaker than in the morning, high temperature exsisted toward coast area. When the moisture were gone, all Bandar Lampung area had similar dryness and therefore air temperature was similar because not many buildings covered Bandar Lampung land surfaces. In Jakarta, however the UHI existed stronger; it showed that cities central area with crowded buildings emitted more radiation to the atmosphere.

In the evening UHI was not identified in both cities. When the solar radiation decreases, source of air temperature is from earth emission which are weak and does not depend on land cover type. Sattelite observations showed that temperature difference between area surrounding the city and the city central existed in Bandar Lampung, while Jakarta looked like a big hot island. It did reflect the land cover in a big scale, however to study $\mathrm{UHI}$ in community level direct measurement of air temperature in surface level is more applicable.

\subsection{Vulnerability Index for the Survey Area}

Vulnerability index is composed of exsposure and sensitivity. The assessment of exposure was compiled from the community knowledge about climate change and temperature rising and the observed air temperature. The sensitivity was composed of water availability, health related to temperature rising, electricity need; and the adaptive capacity was composed of social relationship, education, income and house environment. Averages and standardised of main indicators indices and the livelihood vulnerability indices (LVI) value which is the weighted average of all indices for Bandar Lampung and Jakarta was presented in Table 3 while the description details for the survey area were as follow. 
Manik and Syaukat; BJECC, 7(2): 119-134, 2017; Article no.BJECC.2017.010

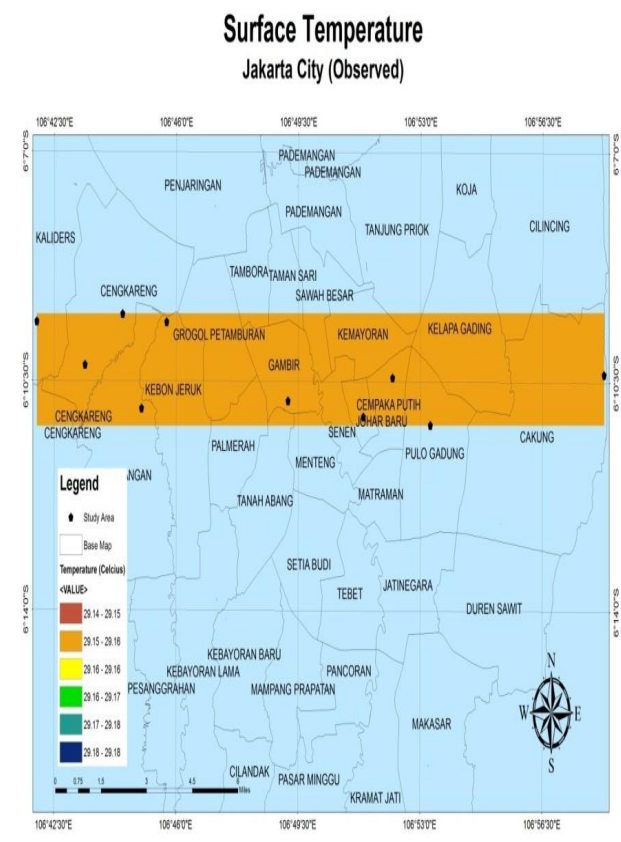

(a)

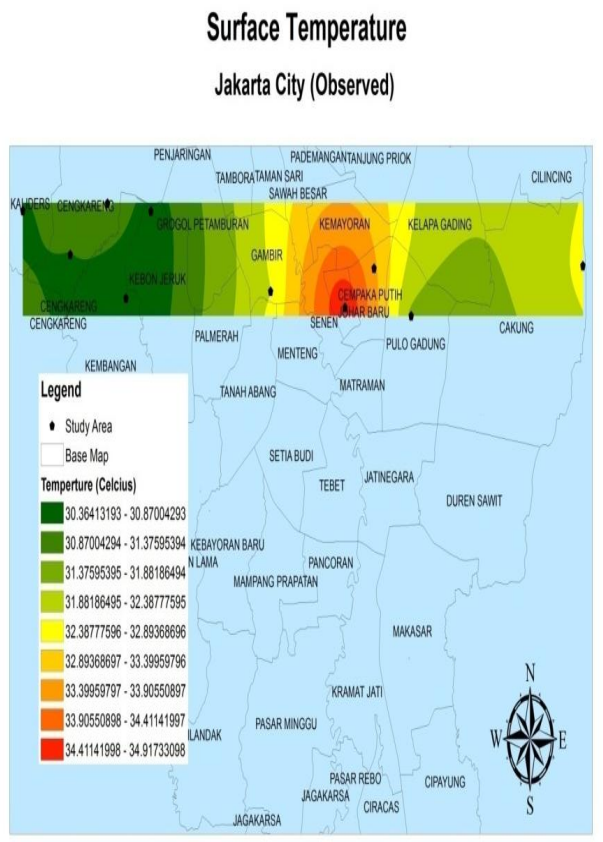

(b)

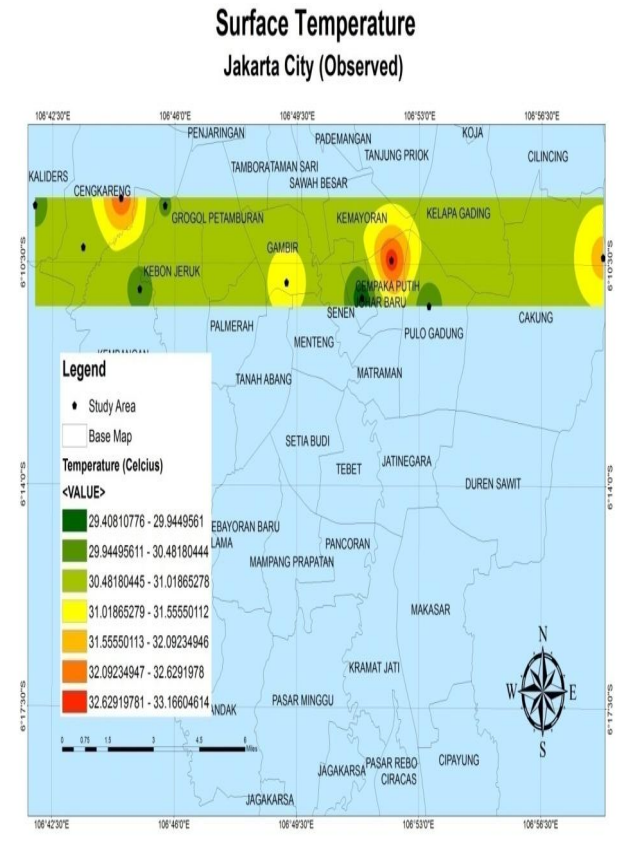

(c)

Fig. 4. Spatial distribution of observed morning, noon and evening air temperature in Jakarta 

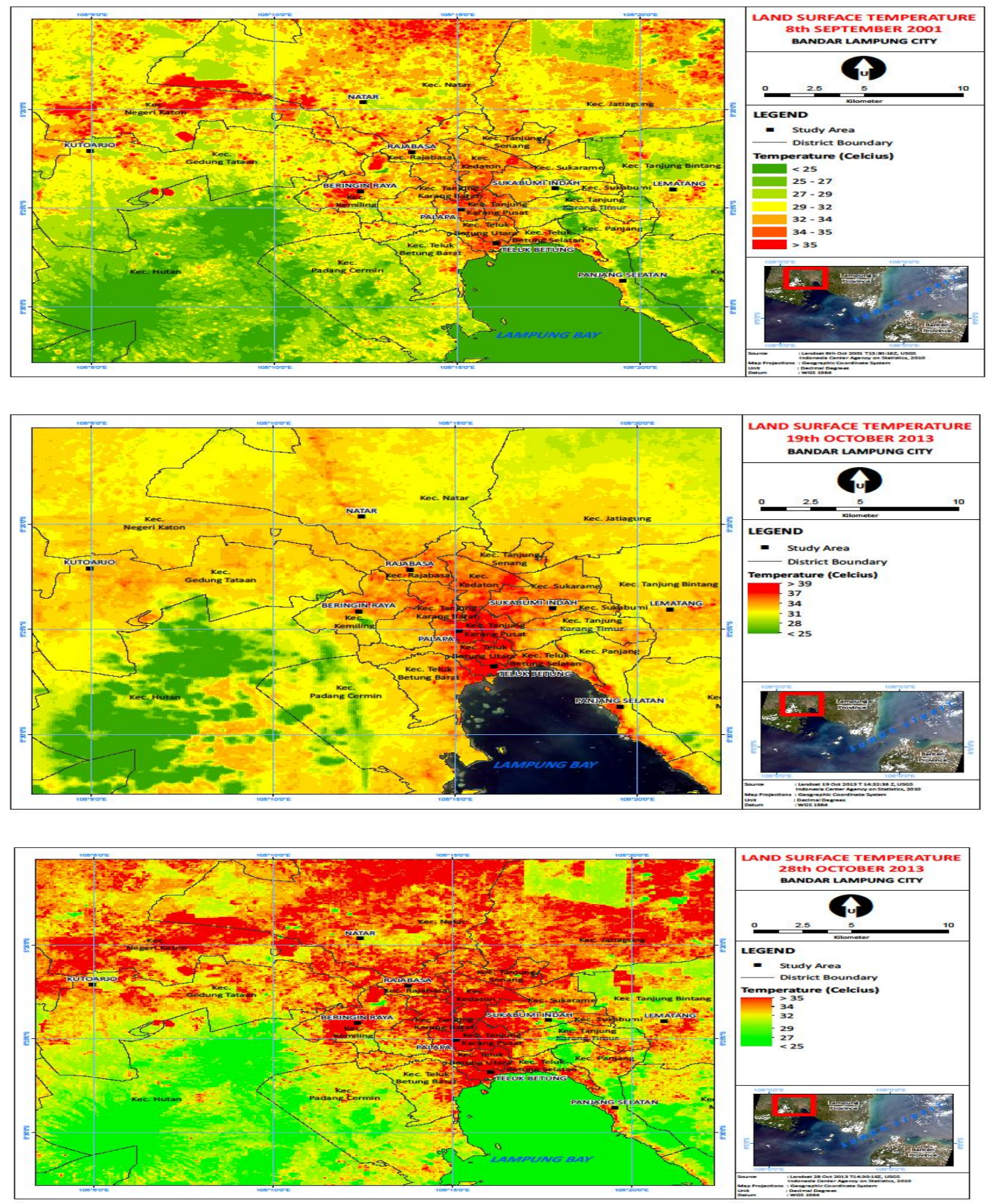

Fig. 5. Surface temperature of Bandar Lampung at September $8^{\text {th }}$, October $19^{\text {th }}$ and October $28^{\text {th }} 20013$, respectively

\subsubsection{Bandar Lampung}

The highest index in term of not getting information about climate change for communities in Lampung was $0.6 ; 0.275$ of not realizing the temperature rising, and 0.7 to 0.875 of not knowing the cause and the impact of temperature rising. Most of the community in the area of agriculture did not experience or realize temperature rising while the community along 
coast area and fisheries communities in general has low education that they did not pay attention to the temperature rising. Results from air temperature observation show that comercial area in Bandar Lampung had the highest temperature rising index (0.549) and the agriculture area was the lowest (0.361). Aggregated those subjects, the highest index of exposure to disaster in Bandar Lampung area arranged from 0.490 to 0.426 and this was mostly caused by low knowledge of climate change or rising temperature issues.

A residential area on the hills had the highest sensitivity index in term of water availability (0.499) followed by an area of industries and manufacturers. Households in those areas depend on natural water resource for their needs, no clean water installation was built in this area, in fact this is common clean water problems in Bandar Lampung. In coastal area where clean drinking water was limited, the households in this area had to buy clean water; then the index for water cost was high (0.477).
Averaging from those factors, commercial area had the lowest index (not sensitive) in term of water availability $(0.275)$ probably people who are doing business in that area did not live there.

The highest sensitivity index in term of health was 0.490 in industrials area. High index did not necessary came because of illness caused by rising temperature but mostly because households do not have any health insurance and no financial support available when they were sick. Health sensitivity index did not relate to area/locations. The sensitivity index in term of electricity in Bandar Lampung was almost similar to all areas (0.3-0.4). All households in Bandar Lampung use electricity but with limited capacity, therefore most households had not increased the electricity capacity due to rising temperature. The survey showed that in all areas households did not involve in any program related to environment Therefore, the index of social relationship was $(0.244-0.456)$ because most of all households did not know about such program probably because no such program existed in the
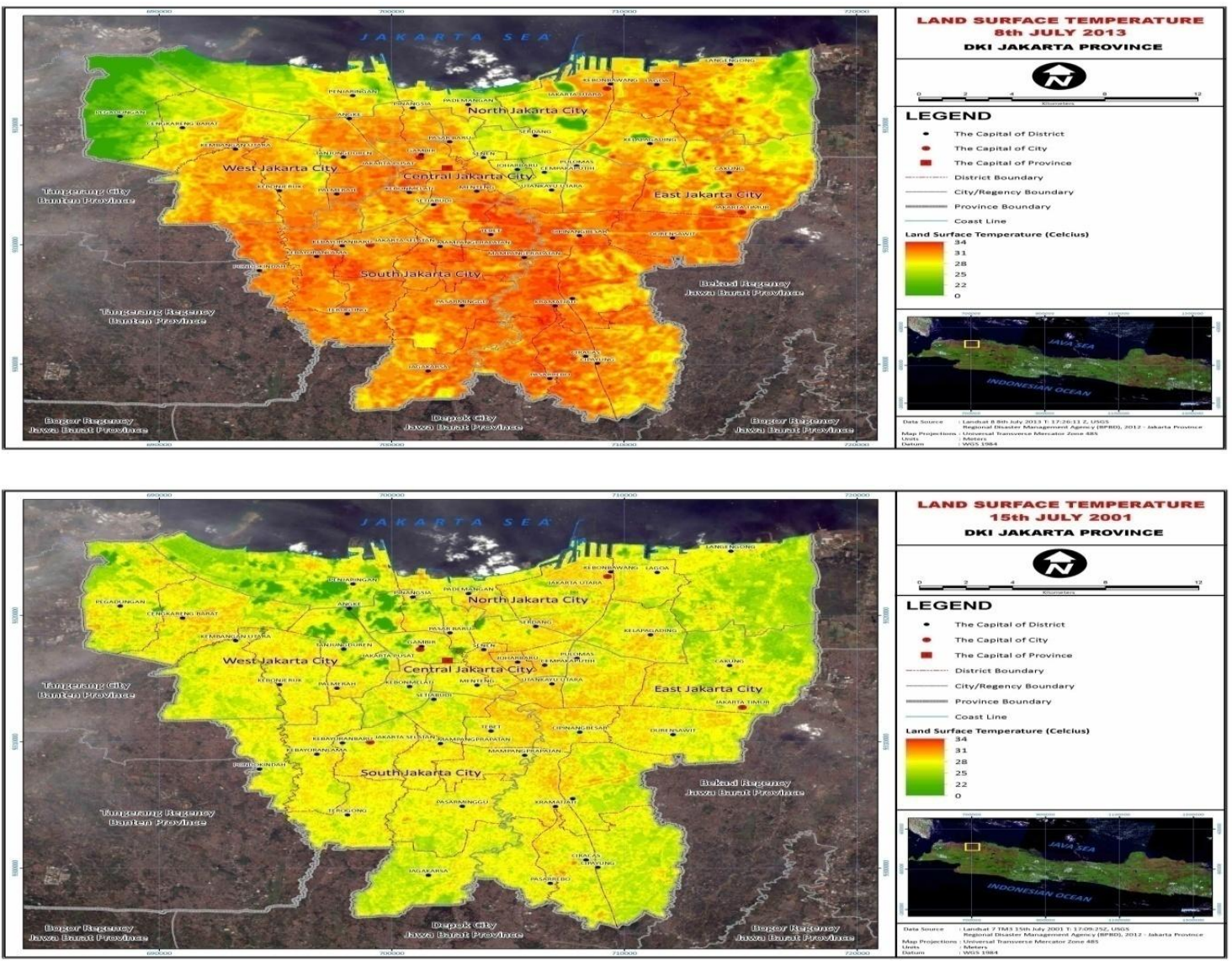

Fig. 6. Surface temperature of Jakarta at July $8^{\text {th }}$ and $15^{\text {th }} 2013$ 
survey areas. Three areas that had low capacity in term of education (index $0.4-0.5$ ) were in agriculture areas that most of the young people went to the other places for education or for working while in an industrial area most of them were contract labours that had low education. Most of the households in Bandar Lampung has self (spontaneous) adaptation related to air temperature such as having enough ventilation (windows) or using fan/AC; also most of their houses had trees planting on their yards. Therefore the index of house environment and adaptation were low which was in range of 0.097-0.270 that meant they had high self adaptive capacity.

\subsubsection{Jakarta}

The index of households that did not have knowledge about climate change and temperature rising -including not getting information about climate change, not realizing of temperature rising, not knowing the cause and the impact of temperature rising- in Jakarta was ranged from 0.238 to 1.0. The highest index for climate variability was 0.345 . Therefore, Jakarta index in term of exposure to natural disaster and climate variability was 0.441 .

Some area in Jakarta have serious problem about clean water availability while in other area clean water was not a problem. Therefore the index ranged from 0.9 to 0.220 . High index in term of health (0.534) mostly came from households that suffered from illness related to air temperature, high cost of health care and no health insurance. All households in Jakarta used electricity and did not have problems with electricity availability. The sensitivity index was different among the area $(0.212-0.336)$ mostly because of various needs and eventually various electricity cost.

Households involvement in social organization in Jakarta survey area was quite low; the index was $0.636-1.00$ for not active, when actually they knew about the organization and program -most index for not knowing was 0 . The households in Jakarta survey area had low education, the indices were 0.524 to 0.450 . All households in survey area had adequate income and some with additional income source; the index was 0.383 to 0.417 . All households in the survey area did not do any house adjustment because of air temperature; all households have fan/AC because in general Jakarta is a hot city. Most of houses in the area did not have green open space area with trees on it. In general the index for this subject was similar 0.337- 0.394.

\subsubsection{Analysis of livelihood vulnerability index (LVI) comparing Bandar Lampung and Jakarta}

For main indicator of natural disaster and climate variability Bandar Lampung was more vulnerable than Jakarta (the index was 0.317 compare to 0.210 ). The households in Lampung had lower knowledge of temperature rising and the impact of it compared to Jakarta ( 0.250 compare to 0.05 and 0.458 to 0.243 ). Bandar Lampung had not yet experienced significant temperature rising that the community did not pay attention to it. For water availability Bandar Lampung was more vulnerable compared to Jakarta (0.405 to 0.266 ). The main water problem in Bandar Lampung was households depended much on water natural resource; the government water installation had not reach most area in this city (the index was 0.867 ), also water was not efficiently used (the index was 0,659 ). Jakarta had water problem in general probably because of limited availability.

For health related to temperature rising both Bandar Lampung and Jakarta had similar index (0.304 to 0.319). Health problems happened mostly because most households did not have health insurance and no alternative aids for health care. Indonesia government just launched a national health program started in January 2014. This scheme hopefully will resolve health care problems for most of Indonesian people. For electricity Bandar Lampung had higher index compared to Jakarta (0.344 to 0.270). Households in Bandar Lampung had not done any adaptation yet to the air temperature by installing air conditioner for instance; also electricity used was not efficient. In fact, Bandar Lampung experienced electricity shortage that blackout happened often in this city.

For social relationship Bandar Lampung community had a better condition compared to Jakarta (0.339 to 0.440$)$. As bigger city Jakarta people was more individualistic compare to Bandar Lampung, however, most survey area showed that community programs related to environment were rare in Bandar Lampung compared to Jakarta. For education and income there was not much difference between Bandar Lampung and Jakarta (0.247 to 0.265 and 0.400 to 0.370$)$. The education showed that in both cities low education was still dominated the people, which indicated a low adaptive capacity. 
For Housing environment Bandar Lampung had much better condition compared in Jakarta (0.179 to 0.311$)$, As smaller city with agriculture background houses in Bandar Lampung had more open space (house yard) with trees planting on it compared to Jakarta. In conclusion, LVI index which calculated from weighted average of all indicators showed that Bandar Lampung had slightly lowest vulnerability index (0.303) compared to Jakarta (0.311).

Table 3. Averages standardized of main indicators for the LVI of Bandar Lampung and Jakarta

\begin{tabular}{lll}
\hline Sub component & $\begin{array}{l}\text { Bandar } \\
\text { Lampung }\end{array}$ & Jakarta \\
\hline $\begin{array}{l}\text { Natural disaster and } \\
\text { climate variability }\end{array}$ & 0.317 & 0.21 \\
$\begin{array}{l}\text { Water availability } \\
\text { Health related to }\end{array}$ & 0.405 & 0.266 \\
temperature rising & 0.304 & 0.319 \\
$\begin{array}{l}\text { Electricity needs } \\
\text { Social relationship }\end{array}$ & 0.344 & 0.319 \\
$\begin{array}{l}\text { Education } \\
\text { Income }\end{array}$ & 0.339 & 0.44 \\
$\begin{array}{l}\text { Housing } \\
\text { environment }\end{array}$ & 0.4 & 0.265 \\
LVI & 0.179 & 0.37 \\
\hline
\end{tabular}

Table 4. LVI-IPCC calculation for Bandar Lampung and Jakarta

\begin{tabular}{lll}
\hline $\begin{array}{l}\text { Contribution } \\
\text { factor }\end{array}$ & $\begin{array}{l}\text { Contribution } \\
\text { factors } \\
\text { indices }\end{array}$ & $\begin{array}{c}\text { LVI-IPCC } \\
\text { results }\end{array}$ \\
\hline \multicolumn{3}{c}{ Bandar Lampung } \\
\hline Adaptive capacity & 0.348 & -0.011 \\
Sensitivity & 0.355 & \\
Exposure & 0.317 & \\
\hline \multicolumn{3}{c}{ Jakarta } \\
Sensitivity & 0.269 & -0.017 \\
Exposure & 0.285 & \\
\hline
\end{tabular}

3.3.4 LVI-IPCC analysis for Bandar Lampung and Jakarta

Aggregated the natural disasters and climate variability as exposure indicator, Bandar Lampung was more exposed to natural disaster than Jakarta (the index was 0.317 compared to 0.210). Temperature might be higher in Jakarta but because the society in Bandar Lampung had not realized the air temperature rising yet and did not have knowledge about the impact of climate change in general, including the temperature rising, Bandar Lampung had higher exposure index compared to Jakarta.

Bandar Lampung was also more sensitive to the possibility of problems caused by rising temperature (the index was 0.355 compared to 0.285) composed from water availability, health care and electricity. Bandar Lampung needed to improve its public facilities; for water availability because the high dependences on natural resource, for electricity capacity because its limitation and to health facilities especially the access for fair health care.

Because of better social relationship and better housing environment Bandar Lampung had better adaptive capacity compare to Jakarta (the index was 0.348 compared to 0.269 ); however, this was more a natural spontaneous adaptive capacity; it was not the result of community ability in dealing with climate change or temperature rising. Most areas did not have any programs or activities to increase the community capacity in understanding and responding to the impact of climate change.

\section{CONCLUSION}

UHI was identified both in Jakarta and Bandar Lampung which related to the land cover in general. Eventough land cover impacts were not investigated in this study but it could be implied that vegetated area has lower air temperature because of its moist air. Jakarta high temperature happened because of human activities in high density urban area and high buildings radiation emission.

LVI value calculated from weighted average of all indices related to the $\mathrm{UHI}$ indicated that Bandar Lampung had slightly lowest vulnerability index (0.303) compared to Jakarta (0.311). In Bandar Lampung, the community in coastal area and industrial area needed more attention since they had the highest vulnerability index $(0.353$ and 0.336). The coastal area was almost like slum area that probably related to the low income of fisheries activities while in the industrial area most of the people worked in manufacturing as contract labors. Similar condition in Jakarta, the industrial and high density settlements had the highest vulnerability index (0.384 and 0.359$)$. It seems vulnerability in the survey areas related more to economic level than to environment condition.

The LVI-IPCC index which aggregated and categorized those indices as exposure (e), 
sensitivity (s) and adaptive capacity (a) and calculated the vulnerability index by $(e-a)^{\star} s$, also indicated that Bandar Lampung was slightly less vulnerable compared to Jakarta (-0.011 compared to -0.017) and both were categorized as moderate since the index range from -1 (low vulnerability) to 1 (high vulnerability). Bandar Lampung was low in term of communities knowledge about climate change and also in public facilities; however it had high score in adaptation even though that adaptation was more natural and spontaneous adaptation, not because they realized the impact of temperature rising. Jakarta sensitivity happened because the communities in the surveyed area suffered from hot days, some area had adequate public services, better income and education level but some other areas lacked of that. Jakarta had low index in adaptation mostly because of low participation in communities program especially the one related to environment.

\section{ACKNOWLEDGEMENTS}

This research was supported by The International Institute for Environment and Development Fund. The Authors would like to acknowledge Dr. Diane Archer, Dr. David Dodman, Dr. Adrian Hayes for their valuable mentoring and guidances in conducting this research and writing the report; field teams both in Bandar Lampung and Jakarta especially during the processes of interviewing the communities and filling the long questionnaires.

\section{COMPETING INTERESTS}

Authors have declared that no competing interests exist.

\section{REFERENCES}

1. World Bank. The rise of metropolitan regions towards inclusive and sustainable regional development.

(Accessed 13 August 2014)

Available:http://tinyurl.com/wb-rise-metroIndonesia-2012

2. Jongtanom Yenrutai, Charnwit K. Temporal variations of urban heat island intensity in three major cities, Thailand. Environmental Science (Interdisciplinary Program) Graduate School, Chulalongkorn University; 2011.

3. Allen L, Lindberg F, Grimmond CSB. Global to city scale urban anthropogenic heat flux: Model and variability. Int. J. Climatol. 2010;31(13):1990-2005.

4. Watkins $R$, John $P$, Maria K. Increased temperature and intensification of the urban heat island: Implications for human comfort and urban design. Built Environment Climate Change and Cities. 2007;33(1):85-96.

5. Wenga, Qihao, Dengsheng L, Jacquelyn S. Estimation of land surface temperaturevegetation abundance relationship for urban heat island studies. Remote Sensing of Environment. 2004;89:467-483.

6. Harlan SL, Anthony JB, Lela P,William LS, Larissa L. Neighborhood microclimates and vulnerability to heat stress. Social Science and Medicine. 2006;63:28472863.

7. Whitford V, Ennos AR, Handley JF. City form and natural process- indicators for the ecological performance of urban areas and their application to Merseyside, UK. Landscape and Urban Planning. 2001; 57(2):91-103.

8. United Nations. World urbanization prospects: the 2014 revised highlight (ST/ESA/SER. A352). UN Department of Economics and Social Affairs Population Divisions; 2014.

Available:http://esa.un.org/unpd/wup/

9. Welle T. Vulnerability assessment towards heat waves in urban areas: City of Cologne case study. Vulnerability Assessment, Risk Management and Adaptive Planning Section, UNU-EHS; 2011.

10. Amirtham LR. Urbanization and its impact on urban heat island intensity in Chennai Metropolitan area, India. Indian Journal of Science and Technology. 2016;9(5):617626.

DOI: $10.17485 / \mathrm{ijst} / 2016 / \mathrm{v} 9 \mathrm{i5} / 87201$

11. Elsayed ISM. A study on the urban heat island of the city of Kuala Lumpur, Malaysia. Meteorology, Environment \& Arid Land Agriculture Sciences. 2012; 23(2):121-134.

12. Kim YH, Baik JJ. Maximum urban heat island intensity in Seoul. J Appl Meteorol. 2002;41:651-659.

13. Tiangco M, Sangmay AMF, Argete J. ASTER-based study of the night time urban heat island effect in Metro Manila. International Journal of Remote Sensing; 2008.

DOI: $10.1080 / 01431160701408360$

Available:https://www.landf.co,uk/journals 
14. Rosenthal JK, Rob C, Majora C. New York City's urban heat island mitigation can improve environment. Research on the impacts of mitigation strategies. A Sustainable South Bronx Working Paper; 2008

15. Tan J, et al. The urban heat island and its impact on heat waves and human health in Shanghai. Int J Biometeorol. 2010;54:7584.

16. California Department of Public Health and the Public Health Institute. Public health impacts of climate change in California: Community vulnerability assessments and adaptation strategies. Report No. 1: HeatRelated IIIness and Mortality. Information for the Public Health Network in California. Climate Change Public Health Impacts Assessment and Response Collaborative; 2007.

17. Reid CE, et al. Mapping community determinants of heat vulnerability. Environmental Health Perspective. 2009; 117(11):1730-1736.

18. Koh J. Assessing local vulnerability to climate change and its implications: The case of Gyeonggi-Do. Gyeonggi Research Institute; 2010.

19. Klinenberg E. Dying alone: The social production of urban isolation. Ethnography. 2001;2:501.

20. Kalkstein LS, Davis RE. Weather and human mortality: An evaluation of demographic and interregional responses in the United States. Annals of the Association of American Geographers. 1989;79:44-64.

21. Kalkstein LS, Greene JS. An evaluation of climate/mortality realtionship in large US cities and a possible impact of climate change. Environ. Health. Perspec. 1997; 105:84-93.
22. Hahn MB, Anne MR, Stanley OF. The Livelihood Vulnerability Index: A pragmatic approach to assessing risks from climate variability and change-A case study in Mozambique. Global Environ. Change; 2009.

DOI: 10.1016/j.gloenvcha.2008.11.002

23. Allen $\mathrm{K}$. Vulnerabiility reduction and the community based approach. In: Pelling M, editor. Natural Disasters and Development in Globalising World. 2003;170-184.

24. Blaike P, Canoon T, Davis J, Wisner B. At risk: Natural hazard, people vulnerability and disasters. London, Routledge; 1994.

25. Kazmierczak AJ, Carter G, Cavan SG, Handley J. Green infrastructure contribution to adaptation to climate change in Greater Manchester. University of Manchester, United Kingdom; 2010.

26. Kazmierczak A. Heat and social vulnerability in Greater Manchester: A risk response. Case study. University of Manchester. School of Enviromental and Development. Oxford, UK; 2012.

27. IPCC. Climate change. Impacts, adaptations and vulnerability. Contribution of Working Group II to the Fourth Assesment Report. Cambridge University Press. Cambridge, UK; 2007.

28. Klein RJT. Developing a method for addressing vulnerability to climate change and climate change impact management: To index or not to index. German Watch, Bonn, Germany; 2004.

29. Sailor DJ. Urban heat islands: Opportunities and challenges for mitigation and adaptation. National Institute for Global Environmental Change School of Engineering, Tulane University. North American Urban Heat Island Summit Toronto, Canada 1-4, May; 2002.

(C) 2017 Manik and Syaukat; This is an Open Access article distributed under the terms of the Creative Commons Attribution License (http://creativecommons.org/licenses/by/4.0), which permits unrestricted use, distribution, and reproduction in any medium, provided the original work is properly cited. 